\title{
Animals Theme in Indonesian Nursery Rhymes Era 1970 - 1990 an: A Study of History, Language, and Education
}

\author{
Raden Muhammad Mulyadi*, Nani Darmayanti \\ Faculty of Cultural Sciences, Universitas Padjadjaran \\ *Corresponding Author: Raden Muhammad Mulyadi, Faculty of Cultural Sciences, Universitas \\ Padjadjaran, Indonesia
}

\begin{abstract}
Indonesian nursery rhymes are part of the collective memory of the Indonesian nation since every children generation has anown rhymes. The main priority of this research is the correlation between Nursery rhymes and collective memory. This research is focused on the collective memory about animals found in the era of the 1970s to the 1990s and examined using historical, linguistic and educational approaches. This research was conducted using descriptive qualitative methods with nursery rhymes which were popular in the 1970-1990s. The results showed that Indonesian nursery rhymes in the era of 1970-1990s depicted the natural life and its surroundings, including describing the animals around it, both pets, and wild beast. In addition, Indonesian nursery rhymes depicted onomatopoeic sounds of the animal, and described the character of the animal, as well as the child's attitude towards the animal. This shows that Indonesian nursery rhymes from the 1970s to 1990s were closely related to the educational content of introducing animals to children.
\end{abstract}

Key Words: Nursery Rhymes, Animals, History, Onomatopoeia, Education

\section{INTRODUCTION}

Based on the purpose of its creation, nursery rhymes can be divided into two types, namely first is for education and second is for the benefit of the music industry. Nursery rhymes which is created for education are usually created to be sung as singing lessons for children of preschool or pre-school students up to elementary school level. Some of nursery rhymes that are part of the world of education in Indonesia were created by educational figures such as A.T. Mahmud, Daldjono, Mrs. Kasur, and Mr. Kasur. [1]

Meanwhile, nursery ryhmes aimed at the interests of the music industry were created to encounter the entertainment market for children. Nursery rhymes that are known in the music industry are packaged in record albums in the form of cassettes, CDs and VCDs, which are then sold to the public. The famousof nursery rhymeswriters in the music industry are Papa T. Bob and Nomo Koeswoyo. In the early 1970s Koes Plus, which is a famous band at that time also had time to make a children's recording album.

In Indonesia, nursery rhymes are well known, both created for education and for the music industry, are not strictly separated, but can be interrelated. Nursery rhymes for education, for example, are often also produced in recording albums as part of the music industry that is for sale, while the nursery rhymes for the music industry can also be sung by children at school as a form of learning.

Rhymes are the things that can be neglected in music. In vocal music, words have an important role as it describes the content or the message of the song. Nursery rhymes are a kind of expressions and those express several things that can shape the children's personality. Besides being useful in expressing feelings, songs also become creators to realize themselves as a whole as one of the needs of human life (Goble, 1987). [2]

Until the late 1970s, Nursery rhymes in Indonesia are a representation of the country itself which still has an agrarian state. There is such memory that can be taken on youtube" Best Nursery rhymes Album of All Time uploaded on youtube https://www.youtube.com/ watch?v=Zbq-FsLel2Q.

It was about twenty five nursery rhymes in the album, there are three songs with the theme of natural phenomena, namely in the song "Pelangi-Pelangi", "Little Star", and "Bintang Kejora". While the 
song with the theme of rural nature is one song, "Planting Corn". In the album there are also four animal-themed songs or there are names of animals in the lyrics namely "Chicks", "Kukuruyuk", "Naik Delman", "PokAme-ame", and "Owl"

Rasyid (2010: 148) states that good songs for children must pay attention to the criteria (1) rhyme is not too long, (2) easily memorized by children, (3) there is an educational goals, (4) adjusted by character and children world, (5) the tone taught is easy to master. [3]

In addition, rhymes are an idea and creator's thought containing a message to be conveyed to the listeners through the song written. Thus song lyrics for children should include the formation of children's behavior in terms of moral education, discipline, adherence to teachers and parents, the spirit of nationalism, loving friends, and the introduction of matters related to learning for children. In addition, nursery rhymes are expected to be able to improve children's abilities, especially in terms of language development, thinking, creativity and children's skills.

Indonesian nursery rhymes has been observed by previous researchers. However, in general, basically research on Indonesian nursery rhymes as a medium for developing educational character. Tyasrinestu (2016) conducted research on Indonesian nursery rhymes from an educational aspect. The results of her research show that Indonesian-language children have some characteristics in the lyrics and musical as a learning medium for learning language creatively besides that it also contains educational values and positive characters with positive meaningful words in the lyrics. [4]

Arostiyani's research (2013) shows that nursery rhymes can be used as a medium for character education in early childhood. The process of character education occurs when the teacher teaches nursery rhymes and explains the content or meaning founded in the nursery rhymes itself. [5]

Putra, et al (2018) conducted research on learning activities at ECO BambuCipaku. The results of his study showed that ECO BambuCipake used the exposition method with the aim that the transfer of knowledge in the form of character values provided by the facilitator could be well received by the learning community. The facilitator revises and adds song verses to some of the kakawihan pieces in the traditional game. This is to create quality and quality learning output. [6]

Meanwhile the results of Sulistyani's research (2015) show that the songs of children in ancient times did not pay much attention to the words, but rather pay attention to the suitability of the tone and rhyme at the end of each sentence. The words used also tend not to be good and correct Indonesian, such as the use of words in the first sentence or line, in the second sentence or line, and so on. [7]

The previous description shows that nursery rhymes research is generally reviewed based on education or language. Not many studies of Indonesian nursery rhymes have been reviewed based on history and language. This overlap will be filled by this research. This research will examine how the collective history of the Indonesian people is reflected through the language of Indonesian nursery rhymes with animal themes.

In relation to education, singing is an activity that is very liked by children when studying in class or outside the classroom. Therefore, early childhood teachers really use this activity as a means to convey messages or effective and best tools when the child is in the learning process.

Therefore, this study is aimed to examine the development of nursery rhymes in Indonesia which are limited to animal-themed songs. This animal-themed nursery rhymes will be examined based on three aspects, namely based on history, linguistics (Onomatopoeia), and education.

\section{RESEARCH METHODS}

This study uses a qualitative method by paying attention to nursery rhymes which became the collective memory of Indonesian children in the 1960-1990s. The popular parameter in the research refers to nursery rhymes in the recording industry by measuring the number of recorded album sales, print media coverage, and referring to songs that were considered legendary by Indonesian people in the 1960-1990s.

Data collection was carried out through a literature study on the printed mass media in the form of newspapers and magazines during the 1960-1990s period at the National Library of the Republic of Indonesia in Jakarta to see mass media coverage of popular nursery rhymes during the research 
period. Newspapers that are searched are national newspapers that prioritize entertainment columns, while magazines that are searched are magazines that prioritize entertainment such as MIDI and Ekspress magazines. In addition, search is also carried out through online media. Searching is done by searching websites that contain children's world entertainment and nursery rhymes channels on YouTube.

After reviewing media coverage of nursery rhymes during the study period, the data was then selected based on the album sales figures and viewers on YouTube online media. Popular songs are songs that are in the hundred thousand to one million sales figures. And it's in the number five hundred viewers / viewers on YouTube online media videos.

The data that has been collected is then analyzed based on historical and linguistic aspects. The historical aspect examines Indonesian nursery rhymes based on malatari social and cultural settings when the song was popular in its time. The linguistic aspect examines Indonesian nursery rhymes based on the onomatopoeia contained therein. In addition, the data were also analyzed based on animal characters and children's attitudes towards animals in the song.

\section{RESUlts AND Discussion}

\subsection{Historical Aspects in Animal-themed Nursery Rhyemes}

Nursery rhymes have been developing in Indonesia since the 1950s, precisely when one of Indonesia's nursery rhymes heroes, SaridjahNiung, or better known as Ibu Soed, actively creates nursery rhymes. In the '60s, nursery rhymes blossomed even more, when the Television of the Republic of Indonesia initiated the Let's Sing and air program for the first time on June 3, 1968. At that time, Abdullah Totong (A.T. Mahmud) was appointed as the coordinator of the Come Singing event.

Let's Sing presents new elementary school nursery rhymes so that people who are talented in the field of music can send their work to this event. Besides Come Singing, TVRI also had a chance to create a nursery rhymes competition called My Choices. Both events lasted for 20 years, but then ended in 1988.

In the 1970s, the Indria Park children's program also appeared, which was hosted by two educational figures as well as nursery song writers, Pak Kasur and Ibu Kasur. In this event, the children showed their talents in the TVRI studio. Reliable music professor and composer TjutNyakDevianaDaudsjah also called the decade of the $60 \mathrm{~s}$ and $70 \mathrm{~s}$ a golden age for nursery rhymes.

He told me, besides being treated to many nursery rhymes sung by children singers, at that time the children always sang songs which were mostly composed by Mrs. Soed and A.T. Mahmud In the mid '60s and' 70s, nursery rhymes on TVRI were still lively and were heard a lot by the public. (CNNIndonesia.com, 2020). [8]

Some popular nursery rhymes usually tell the story of the environment where he grew up. The majority of Indonesian people lived in the countryside until the mid 1980s so most of the songs created were songs with rural phenomena.

It is also in line with other art that also takes on the theme of rural nature, can be seen for example in mass paintings that are often sold on the side of the road and even sold around villages and cities until the 1980s are paintings about the rural nature, usually in the painting in the form of views of rice fields and rivers in the countryside. Mass paintings of rural nature can also be seen in paintings on the highway such as those found in trucks and buses or rickshaws.

In addition to the majority of Indonesians living in rural areas, the urban environment in general is still rural. In the city of Bandung, for example, until the 1980s there were still some rice fields. With this description we can imagine the condition of other cities smaller than Bandung. In addition to nature-themed songs, one of the features that characterize popular nursery rhymes is the animal theme. This is even what distinguishes it from adult songs that are rarely animal-themed.

Animals are often attracting for children, so songwriters make animal-themed songs. The animals that are mostly used as the title of a song or the contents of a nursery ryhmes are divided into two classifications, namely (1) pets and (2) wild beast. 
Many pet animals that become song titles or parts of nursery rhymes are birds, chickens, ducks, dogs, and cats. Songs about dogs as pets are very rare in Indonesian nursery rhymes. Likely as a country with a majority of Muslims, dogs are rarely used as nursery rhymes themes. There is only one popular nursery rhymes about dogs, namely the song titled "Helly" which was popularized by ChichaKoeswoyo in the mid-1970s. Here are the titles of nursery rhymes from the 1970-1990s that contain pet names.

Table1. Indonesian Nursery Rhymes Title Animal Themed

\begin{tabular}{|l|l|l|}
\hline No & Song Title & Creator \\
\hline 1. & Parrot & R.C. Hardjosubroto \\
\hline 2. & Owl & AT Mahmud \\
\hline 3. & Sooty-headed Bulbul & Mrs. Sud \\
\hline 4. & Chicks & AT Mahmud \\
\hline 5. & Kukuruyuk & Nadja Dirja \\
\hline 6. & Cut the Goose Duck & Soerjono / Pak Mattress \\
\hline 7. & My ducks & Is Haryanto \\
\hline 8. & Helly Woof WoofWoof & Nomo Koeswoyo \\
\hline 9. & Sweet Pussy & Is Haryanto \\
\hline 10. & My cat & Soerjono / Pak Mattress \\
\hline
\end{tabular}

Table 1.1 above shows that animals that are rarely used as nursery rhymes themes are animals that live in the sea. This shows that the influence of agrarian culture is so strong that Indonesian people rarely pay attention to the sea. There are only three popular sea-themed nursery rhymes, "KapalApi", "Let's Go to the Sea" and "The Dolphin". The first two songs, "KapalApi" and "Mari KeLaut", were originally nursery rhymes that were usually sung in schools, then recorded for the music industry. While the song "The Dolphins" is a children's pop song, this song is the only popular sea animal song. The song is a children's pop song sung by BondanPrakoso in the 1980s, following fragments of the song "Dolphins":

In addition to sea animals, animals that live in the forests are also not many themes or are mentioned in nursery rhymes. Animals in the forest are more often mentioned in music industry goal than in education goal. Forest animals are such as elephants, tigers, orangutans and monkeys.

Until the 1970s there was only one popular children's pop song by mentioning animals that are rarely mentioned in the treasures of nursery rhymes, the song was titled "Taman Mini Indonesia Indah" which was popularized by ChichaKoeswoyo. In the song mentioned rare Indonesian animals that live in forests and unique areas of habitat such as dragons, birds of paradise, anoa, and orang-utans.

Some animals that live in the forest only emerged again in the mid 1980s through a song called "The Elephant" which was popularized by Ria Enes. Some of the animals in the forest mentioned in the song include elephants, tigers, deer, bees and monkeys.

One animal that is rarely mentioned in nursery rhymes and later became popular among Indonesian children in the 1990s is the Komodo dragon. The popularity of the Komodo dragon grew along with the popularity of the song entitled "The Komo Via the Toll Road" as the theme song of the entertainment and education (edutainment) "The Komo" at the Indonesian Education Television station in the early 1990s. Through songs in the television program, the Komodo dragon became more widely known among Indonesian children.

Many animals live in rural nature, especially in rice fields, illustrate the closeness of the environment that is agrarian nuanced with nursery rhymes. Among the children's pop songs titled "Frogs" is the song "Sang Bango" which was popularized by Bing Slamet and also Benjamin S in the 1960s and "Toad" which was sung by YoanTanamal and was popular in the 1970s.

\subsection{Linguistic Aspects (Onomatopoeia) in Animal-themed Nursery Rhymes}

Some popular animal-themed nursery rhymes contain an element called onomatopoeia, which is the imitation of the sounds and sounds of animals being sung. Onomatopoeia is a word formed as a result of sound imitation. That is the names of objects or things are formed based on the sound of the object or the sound generated from the object (Chaer, 2009: 45). [9] The use of animal sounds in nursery rhymes has a purpose, in addition to being interesting as well because in general the recognition of the 
environment in children begins with the introduction of the names of animals. Below are five data from nursery rhymes from the 1970s to 1990 s that contain onomatopoeia.

Table2. Onomatopoeia in Indonesian Nursery rhymes

\begin{tabular}{|l|l|l|l|}
\hline No & Animal & Rhyme Title & Onomatopoeia \\
\hline 1 & Bird & a. Sooty Headed Bulbul & Tri lililililililili \\
\hline 2 & \multirow{2}{*}{ Bird } & a. Owl & kukukkukukkukukkukuk \\
\cline { 3 - 4 } & & b. Cicitcuit & citcitcitcitcuit. \\
\hline \multirow{2}{*}{3} & Duck & a. My quacks & kwekwekwekwek \\
\cline { 3 - 4 } & & b. My ducks & kwekkwek \\
\cline { 3 - 4 } & \multirow{2}{*}{ Chicken } & c. Cicitcicitcuit & kwekkwekkwek \\
\cline { 3 - 4 } & & a. Kukuruyuk & Kuku kukukukuruyuk..... \\
\cline { 3 - 4 } & & c. Kukuruyuk & kukuruyuk \\
\cline { 3 - 4 } & & d. Chicks & kukuruyuk \\
\cline { 3 - 4 } & & e. Cicitcuit & tekkotekkotek \\
\hline 5 & Dog & a. Helly & toktoktoktokpetok \\
\hline 6 & Cat & a. Sweet Pussy & Guk...guk...guk.... \\
\cline { 3 - 4 } & & b. My Cat & meong-meong \\
\cline { 3 - 4 } & & c. Mow-meow cat & meongpmeong \\
\cline { 3 - 4 } & & d. Eaten & mongmeongmeong \\
\hline
\end{tabular}

The structure of onomatopoeia in nursery rhymesare divided into three types. (1) Onomatopoeia is one syllable (mono-syllable). (2) Onomatopoeia in the form of two syllables (bi-syllable), and (3) Onomatopoeia in the form of three or more syllables (multi-syllable). Data (2b) citcit, (4e) Tok TokTok, and (5a) Woof WoofWoof are woof data showing onomatopoeic sounds in the form of one syllable (monosyllable). Data (2a) cuckoo cuckoocuckoo, (3a-c) quack quackquack (4a) nails nails and (6a-d) meow meow are onomatopoeia data with two syllables, and data (1a), (4b-d), and (6d) is an onomatopoeic data on animal sounds with a multisyllable system.

From some part of the nursery rhymeslyrics above, onomatopoeic chicken sounds consist of three sounds namely kukuruyuk, tekkotek and toktokpetok. The three onomatopoeic chicken sounds represent the roosters roaring or crowing in the morning namely kukuruyuk, then the sound of hens laying eggs in petoktok and the sounds of kotkotekkotek. From the sound of roosters crowing from the nursery rhymes above, they all have the same onomatopoeic sound that is kukuruyuk, while for hens and chickens because there are no similar songs, the onomatopoeia cannot be compared.

The various of onomatopoeic sounds also occurs in bird-themed nursery rhymes. One thing that distinguishes one bird Onomatopoeia with another bird is because the Onomatopoeia is occured is on a different bird species. Not based on sex and age levels as onomatopoeia that occurs in chickens. The following are part of nursery rhymes lyrics about different bird sounds, each titled "Owl" which is a song often sung by children in schools and "CitcitcitCuit" a children's pop song popularized by Joshua The following are the lyrics to the two songs:

Unlike the variety of chicken and bird sounds onomatopoeia in the nursery rhymes above, in the duckthemed nursery rhymes there is no diversity of sounds like Onomatopoeia chicken sounds. Onomatopoe duck sound is not distinguished between the sound of male ducks, females and ducklings, the sound of ducks in all songs about ducks is the same that is wekwekwek, only on Joshua's song which experiences the addition of kowek, so the sound becomes wekwekkowek. The following Onomatopoeia nursery rhymes with a duck theme:

Onomatopoeia uniformity is also found in nursery rhymes with the theme of cats, meow, another popular name for cats for the people of Indonesia is also meow. A designation or naming of animals based on the voice Onomatopoeia, the same thing also applies to dogs that are often also replaced by the name of a woof. Like the sound of ducks, the sound of cats in nursery rhymes also do not recognize the difference between male and female cats and kittens. Here are some fragments of nursery rhymes lyrics that show uniformity in cat voice onomatopoeia:

\subsection{Educational Aspects in Animal-Themed Nursery Rhymes}


Related to education, animal-themed nursery rhymes can also be a means of learning character values for children. Two things that can be learned from animal-themed nursery rhymes are related to movements and attitudes towards animals. Motion of concern in song lyrics is characteristic of animal movements such as jumping, running, dancing and flying. These gestures seem to attract attention to children, or songwriters try to introduce the concept of animal movements to children. Below shows some songs that contain the concept of animal motion.

(1) "My Rabbit"

My rabbit is my rabbit

You are so sweet

Jumping here and there

All day

(2) "Butterfly"

butterfly every day always

dancing doesn't stop

Your flowers are here

dancing alighted once

Butterfly, I'm in

dance together

(3) "The Frog"

Mama see the frog jumping

Mama see ...

(4) "My cat"

Sweet Pussy

Sweet Cat my cat, dear

Every day jumping up and

down

(5) "Sooty-headed Bulbu1"

At the top of cempaka tree

Finches singing

Whistling all day long

With no fatigue

\section{Nodding while exclaiming \\ Tri lilies lilies}

(6) Sooty-headed Bulbu1

Block in the window

Oh dear

Oh dear

The wound wings cannot fly

Oh dear

Oh dear

Let me help

Looking for medicine

(7) $\mathrm{CitCitCitCit}$

citcitcitcuit

the bird sings

Tok TokTokTokTok

Tok TokTokTokTok

come on man

We together

take care of animals

come on

tigers, deer, elephants are also

guarded

don't shoot

do not hunt

protect all animals

creation of God

The data above shows that motion and song are a unity that is carried out by children based on song lyrics. Submission of learning through motion and song will make it easier for children to recognize a concept, because motion and song. In the world of early childhood education, impersonation is also very important for motor training. Impersonation is also often done while singing.

Gross motor skills are divided into three stages, namely the locomotor stage which is a movement with moving places such as walking, running, jumping and gliding. The second stage is the nonlocomotor stage, which is a movement that does not require displacement such as lifting, pushing, pulling and swinging. The third stage is projecting an object, in this stage seen in motion such as catching and throwing a ball in a catch ball game. Child motor development is a basic movement that can be linked to children's health and physical fitness (Sujiono, 2014 in Sumiyati 2017: 86).

Meanwhile, the aspects of attitude towards animals are shown through a number of nursery rhymes which contain invitations to love, love, and do not torture animals. The values of loving and not torturing animals are important for the fine motor development of children so that as adults they grow to be children who have the character of loving, protecting, and not doing acts of violence. Below shows some songs that contain the concept of attitude towards animals.

\section{CONCLUSion}

The results showed that the Indonesian nursery rhymes in the period of 1970-1990 were closely related to the cultural and environmental background that developed at the time. Nature shows 
Indonesia as a beautiful agrarian country and animals live in the wild. His community also shows that they have a habit of nurturing animals. Based on its kind, the animal that made the Indonesian nursery rhymes in the period of 1970-1990 is divided into two, there are types of pets and animals are not pet. Meanwhile, based on the Onomatopoeianya, the Indonesian child song applies the sounds of animal sounds to the lyrics of the song with a two-syllable form of one syllable, and more than two syllable. Some animal-themed nursery rhymes became popular due to the onomatopoeic elements in the lyrics. The onomatopoeia has diversity and diversity. Diversity is a sound that is imitated with similarities in some songs, while diversity is the voice of different animals in some songs. Indonesian nursery rhymes are animal-themed and also contain the value of education for loving animals. Overall this study recommended that the study of nursery rhymes should be carried out always interdisciplinary because the song contains historical value, language, culture, and also education.

\section{BIBLIOGRAPHY}

[1] Mahmud, AT. 2003. "AT Mahmud Meniti Pelangi: SebuahMemoar”. Jakarta: Grasindo.

[2] Goble, G.F. 1987. MazhabKetiga :PsikologiHumanistik Abraham Maslow. Yogyakarta :PenerbitKanisius.

[3] Rasyid, Fathur. 2010.”CerdaskanAnakmudenganMusik”. Jakarta: Diva Press.

[4] Tyasrinestu, Fortunata. 2016. Lagu Anak sebagai Media PembelajaranKreatif Bahasa Anak. Prosiding Seminar Nasional Reforming Pedagogy. Diakses pada 12 Desember 2019. https://www.usd.ac.id/seminar/ snrp2016/wp content/uploads/2017/01/ SNRP07.pdf.

[5] Arostiyani, Devi. 2013. "PemanfaatanLagu Anak-Anak sebagai Media Pendidikan Karakter di Taman Kanak-Kanak Aisyiyah Cabang TonjongDesaLinggapuraKecamatanTonjongKabupatenBrebes" Skripsi. Jurusan Pendidikan Seni Drama, Tari, dan MusikFakultas Bahasa dan SeniUniversitas Negeri Semarang.

[6] Putra, Ari, dkk. 2018. "KomponenPembelajaran Program LiterasiBudaya di Eco BambuCipaku". Jurnal Pendidikan dan Kebudayaan Volume 3 Nomor 2 (2018). Diakses pada 20 Desember 2019. http://jurna ldikbud.kemdikbud.go.id/index. php/jpnk/article/view/921/452

[7] Sulistiyani. 2015. "Mainan Anak: Sebuah Kajian Tagmemik.". JurnalHumaniora Volume 12 No 1 Tahun 2015. Diakses pad 20 Januar 2020. https://www.kopertis7.go.id/uploadjurnal/Humaniora\%20vol\% 2012\%20No\%201\%20Juni\%202015.pdf.

[8] Armenia, Resty. 2018 PerjalananLagu Anak Indonesia dariDekade 50-1n hinggaKini. Majalan CNN Indonesia 24 Juni 2018. Diakses 20 Desember 2019. https://www.cnnin donesia.com/hiburan/20180623 184526-227-308428/perjalanan-lagu-anak-indonesia-dari-dekade-50-an-hingga-kini.

[9] Chaer, Abdul. 2009. PengantarSemantik Bahasa Indonesia Cetakankedua. Jakarta: RinekaCipta.

[10] Sudaryanto. 2018. "Bahasa Indonesia dalamAnimasi 'Lagu Anak Indonesia Bersama Diva' ProduksiKastari Animation”. JurnalRekam, Vol. 14 No. 2 - Oktober 2018.

Citation: Raden Muhammad Mulyadi, Nani Darmayanti. "Animals Theme in Indonesian Nursery Rhymes Era 1970 - 1990 an: A Study of History, Language, and Education" International Journal of Humanities Social Sciences and Education (IJHSSE), vol 8, no. 7, 2021, pp. 52-58. doi: https://doi.org/10.20431/23490381.0807006 .

Copyright: () 2021 Authors. This is an open-access article distributed under the terms of the Creative Commons Attribution License, which permits unrestricted use, distribution, and reproduction in any medium, provided the original author and source are credited. 